\title{
THE ACUTE EFFECTS OF DIFFERENT SPIRONOLACTONE DOSES ON OXIDATIVE STRESS IN STREPTOZOTOCIN-INDUCED DIABETIC RATS
}

\author{
Stefan Simovic ${ }^{1,2}$, Aleksandra Vranic ${ }^{3}$, Petar Ristic ${ }^{4}$, Jovana Jeremic ${ }^{3}$, Ivan Srejovic ${ }^{5}$, Jasna Petrovic ${ }^{6}$, Prof. Vladimir Jakovljevic ${ }^{5,7}$ \\ Stefani Bolevich ${ }^{8}$, Sergey Bolevich ${ }^{7}$ and Vladimir Zivkovic ${ }^{5}$ \\ ${ }^{1}$ Department of Internal Medicine, Faculty of Medical Sciences, University of Kragujevac, Serbia \\ ${ }^{2}$ Clinic for Cardiology, Clinical Center Kragujevac, Serbia \\ ${ }^{3}$ Department of Pharmacy, Faculty of Medical Sciences, University of Kragujevac, Serbia \\ ${ }^{4}$ Clinic of Endocrinology, Military Medical Academy, Belgrade, Serbia \\ ${ }^{5}$ Department of Physiology, Faculty of Medical Sciences, University of Kragujevac, Serbia \\ ${ }^{6}$ General Hospital "Valjevo", Valjevo, Serbia \\ ${ }^{6}$ Department of Human Pathology, $1^{\text {st }}$ Moscow State Medical University IM Sechenov, Moscow, Russia \\ ${ }^{7}$ Department of Pathophysiology, $1^{\text {st }}$ Moscow State Medical University IM Sechenov, Moscow, Russia
}

\section{AKUTNI EFEKTI RAZLIČITIIH DOZA SPIRONOLAKTONA NA OKSIDACIONI STRES KOD PACOVA SA DIJABETES MELITUSOM \\ IZAZVANIM STREPTOZOCINOM}

\author{
Stefan Simović, ${ }^{2}$, Aleksandra Vranić ${ }^{3}$, Petar Ristić ${ }^{4}$, Jovana Jeremić ${ }^{3}$, Ivan Srejović ${ }^{5}$, Jasna Petrović6, Prof. Vladimir Jakovljević ${ }^{5,7}$, \\ Stefani Bolevič ${ }^{9}$, Sergej Bolevič ${ }^{7}$ i Vladimir Živković ${ }^{5}$ \\ ${ }^{1}$ Katedra za Internu medicinu, Fakultet medicinskih nauka, Univerzitet u Kragujevcu, Srbija \\ ${ }^{2}$ Klinika za kardiologiju, Klinički centar Kraguejvac, Srbija \\ ${ }^{3}$ Katedra za Farmakologiju, Fakultet medicinskih nauka, Univerzitet u Kragujevcu, Srbija \\ ${ }^{4}$ Klinika za Endokrinologiju, Vojno-medicinska akademija, Beograd, Srbija \\ ${ }^{5}$ Katedra za Fiziologiju, Fakultet medicinskih nauka, Univerzitet u Kragujevcu, Srbija \\ ${ }^{6}$ Opšta bolnica "Valjevo", Valjevo, Srbija \\ ${ }^{6}$ Katedra za Humanu Patologiju, Prvi moskovski državni univerzitet IM Sečenov, Moskva, Rusija \\ ${ }^{7}$ Katedra za Patofiziologiju, Prvi moskovski državni univerzitet IM Sečenov, Moskva, Rusija
}

Received/Primljen: 16.03.2021.

Accepted/Prihvaćen: 22.03.2021.

\begin{abstract}
Cardiovascular diseases are the leading cause of morbidity and mortality in patients with diabetes mellitus. Increased bioavailability of reactive oxygen species is defined as oxidative stress and is noticed in type 2 DM and reduced antioxidant enzymes expression/activity. Aldosterone, an adrenal hormone, is secreted due to renin-angiotensin-aldosterone system activation, representing one of the fundamental physiological reactions in CVD. Spironolactone, a mineralocorticoid receptor antagonist, uses enhanced coronary microvascular function, suggesting a beneficial role of aldosterone in preventing diabetic cardiovascular complications in patients with type 2 DM. In this study, we evaluated the influence of spironolactone's acute administration on oxidative stress in rats with diabetes mellitus induced by streptozotocin. The present study was carried out on 40 adult male Wistar albino rats (8 weeks old). Rats were randomly divided into 4 groups (10 animals per group): healthy rats treated with $0.1 \mu \mathrm{M}$ of spironolactone, diabetic rats treated with $0.1 \mu M$ of spironolactone, healthy rats treated with $3 \mu \mathrm{M}$ of spironolactone, and diabetic rats treated with $3 \mu \mathrm{M}$ of spironolactone. Spironolactone achieved different effects on oxidative stress parameters when given acutely in different doses in diabetic and healthy rats. In lower doses, spironolactone's acute administration reached lowered parameters of oxidative stress in healthy rats better than higher doses of spironolactone. In contrast, in the diabetic group, acute effects of higher doses of spironolactone lowered oxidative stress parameters better than lower spironolactone doses.
\end{abstract}

Keywords: spironolactone; diabetes mellitus; oxidative stress; rats

\section{SAŽETAK}

Kardiovaskularne bolesti su glavni uzrok morbiditeta i mortaliteta kod pacijenata sa dijabetes melitusom. Povećana bioraspoloživost reaktivnih kiseoničnih radikala je definisana kao oksidacioni stres i primećej je u tip 2 DM kao i redukovana ekspresija/aktivnost antioksidacionih enzima. Aldosteron, adrenalni hormon, se sekretuje kao rezultat aktivacije renin-angiotenzin-aldosteron sistema koji predstavlja jedan od fundamentalnih fizioloških reakcija u kardiovaskularnim bolestima. Spironolakton, antagonist mineralokortikoidnih receptora, koristi pojačanu koronarnu mikrovaskularnu funkciju, sugerišsći delotvornu ulogu aldosterona u prevenciji kardiovaskularnih komplikacija kod pacijenata sa tipom 2 dijabetes melitusa. U ovoj studiji, istraživali smo uticaj akutne primene spironolaktona na oksidacioni stres pacova sa dijabetes melitusom izazvanim streptozocinom. Ovo istraživanje je obuhvatilo 40 odraslih, muških Wistar albino pacova (8 nedelja starosti). Pacovi su nasumično podeljeni $u 4$ grupe (10 životinja po grupi): zdravi pacovi tretirani sa $0.1 \mu \mathrm{M}$ spironolaktona, pacovi sa dijabetesom tretirani sa $0.1 \mu \mathrm{M} \mathrm{spiro-}$ nolaktona, zdravi pacovi tretirani sa $3 \mu M$ spironolaktona $i$ pacovi sa dijabetesom tretirani sa $3 \mu \mathrm{M}$ spironolaktona. Spironolakton je postigao razlicite efekte na parametre oksidacionog stresa kada je primenjen akutno u razlicitim dozama kod zdravih i pacova sa dijabetesom. Unižoj dozi, akutna primena spironolaktona je postigla smanjenje parametara oksidacionog stresa kod zdravih pacova bolje nego veća doza spironolaktona, dok u grupi pacova sa dijabetesom, akutna primena veće doze spironolaktona je smanjila parametre oksidacionog stresa bolje nego niža doza spironolaktona.

Ključne reči: spironolakton; dijabetes melitus; oksidacioni stres; pacovi

Corresponding author: Stefan Simović, MD Department of Internal Medicine, Faculty of Medical Sciences, University of Kragujevac, Svetozara Markovica 69, 34000 Kragujevac, Serbia
Tel: +381644111120 


\section{INTRODUCTION}

Cardiovascular diseases (CVD) are the leading cause of morbidity and mortality in patients with diabetes mellitus (DM). Currently, DM type 2 affects 347 million worldwide [1], while the risk of mortality is 1.7 times higher in patients with diabetes mellitus than in the non-diabetic population [2]. Inflammation, neurohumoral activation and structural remodelling are multiple mechanisms that contribute to cardiovascular disease, whereby one of the primary means contributing to CVD development is oxidative stress [3].

Increased bioavailability of reactive oxygen species (ROS) is defined as oxidative stress and is noticed in type 2 DM and reduced antioxidant enzymes expression/activity [3]. One of the many mechanisms correlated with vascular damage induced by oxidative stress is decreased nitric oxide (NO) bioavailability. NO effects are impaired by increased ROS production whereby increased generation of superoxide anion (O2-), a ROS that readily reacts with vascular NO to form peroxynitrite (ONOO-), has been reported in DM2 experimental models [4].

Aldosterone, an adrenal hormone, is secreted due to renin-angiotensin-aldosterone system (RAAS) activation, representing one of the fundamental physiological reactions in CVD [5]. The discovery that the concentrations of myocardial aldosterone in typical rodents are multiple times higher than plasma prompted an extraordinary comprehension of the role of mineralocorticoid receptor activation in the CVD [6].

Spironolactone, a mineralocorticoid receptor antagonist, produces positive ionotropic actions in rat heart by increasing diastolic concentration of calcium and myosin ATPase calcium sensitivity [7]. This medication utilizes coronary microvascular function, proposing a beneficial role of aldosterone in preventing diabetic cardiovascular complications in patients with type $2 \mathrm{DM}$ [8]. Our previous finding suggests that acute application of different spironolactone doses has other effects on healthy and diabetic hearts; In contrast, the dosedependent effect is observed in diabetic hearts. That effect is absent in healthy ones [9]. Based on the above data, aldosterone affects redox status in multiple ways, whereby cardiacspecific overexpression of human MR leads to increased ROS production and expression of NADPH oxidase [10]. MR blockade with spironolactone treatment in rat led to decreased ROS formation and NADPH oxidase subunit expression [10].

Regarding pro-oxidative and pro-inflammatory effects of aldosterone in the cardiovascular system [11], and considering that aldosterone concentration increases in DM [12], our study aimed to evaluate the impact of different spironolactone dosages on oxidative stress in streptozotocin-induced DM diabetic rats.

\section{MATERIALS AND METHODS}

\section{Animals and experimental design}

The present investigation was done on 40 grown-up male Wistar albino rats ( 8 weeks old and boy weight of $200 \pm 30 \mathrm{~g}$ ). They were housed under controlled natural conditions: temperature $25^{\circ} \mathrm{C}$ with a built-up photo time of $12 \mathrm{~h}$ light/day. The rats had free access to food and water - ad libitum. Rats were randomly randomized into 4 groups (10 animals for each group): (1) healthy rats treated with $0.1 \mu \mathrm{M}$ of spironolactone $(\mathrm{n}=10)$; (2) diabetic rats treated with $0.1 \mu \mathrm{M}$ of spironolactone $(n=10)$; $(3)$ healthy rats treated with $3 \mu \mathrm{M}$ of spironolactone $(n=10)$; (4) diabetic rats treated with $3 \mu \mathrm{M}$ of spironolactone $(n=10)$. Acute administration of spironolactone was achieved through the Langedorff apparatus directly in the isolated heart.

\section{Ethical approval}

All experimental procedures were done per current legislation (EU Directive for the Protection of Vertebrate Animals used for Experimental and other Scientific Purposes 86/609/EES) and ethics standards. Animals were cared as per the Guide for the Care and Use of Laboratory Animals (National Research Council 1996). The study was conducted under the Basic \& Clinical Pharmacology \& Toxicology policy for experimental and clinical studies [13]. The investigation protocol was approved by the Ethics committee for experimental animal well being of the Faculty of Medical Sciences of the University of Kragujevac.

\section{Diabetic rat model}

Before DM induction, 2 weeks of adjustment was given. To build up a rat model of experimentally induced type 1 DM, which imitates similar pathophysiology in the human population, over-night fasting rats were infused with a single intraperitoneal portion of streptozocin (STZ) $(60 \mathrm{mg} / \mathrm{kg})$ (Sigma-Aldrich, St. Louis, Missouri, USA) dissolved down in cold, fresh $0.01 \mathrm{~mol} / \mathrm{L}$ citrate buffer of fresh or solidified $1 \mathrm{~mL}$ aliquots at $20{ }^{\circ} \mathrm{C}(0.1 \mathrm{~mol} / \mathrm{L}$ citric acid, $0.1 \mathrm{~mol} / \mathrm{L}$ sodium citrate), $\mathrm{pH}$ 4.5. DM was confirmed $72 \mathrm{~h}$ later when blood glucose levels were above $11.1 \mathrm{mmol} / \mathrm{L}$. Animals that developed DM were held in similar conditions and followed for the next 4 weeks.

\section{Isolated rat heart preparation}

On the 29th day after inducement of type $1 \mathrm{DM}$, rats were anaesthetized with ketamine $(10 \mathrm{mg} / \mathrm{kg})$ and xylazine $(5$ $\mathrm{mg} / \mathrm{kg}$ ) and afterwards euthanized by cervical disengagement (Schedule 1 of the Animals/Scientific Procedures, Act 1986, UK). Following a fast thoracotomy and quick cardiac arrest by superfusion with super cold isotonic saline, the hearts were speedily extracted and attached to the Langendorff apparatus (Langendorff apparatus, Experimentia LTD, 1062 Budapest, Hungary) through aortic cannulation and 
afterwards were perfused with Krebs-Henseleit solution for retrograde perfusion under continuously expanding coronary perfusion pressure (CPP) (CPP from $40 \mathrm{cmH}_{2} \mathrm{O}$ to 120 $\mathrm{cmH}_{2} \mathrm{O}$ ). Krebs-Henseleit solution was utilized for retrograde perfusion (in mmol/L: $\mathrm{NaCl} 118, \mathrm{KCl} 4.7, \mathrm{CaCl}_{2}$, x 2 $\mathrm{H}_{2} \mathrm{O} 2.5, \mathrm{MgSO}_{4}$ x $7 \mathrm{H}_{2} \mathrm{O} 1.7, \mathrm{NaHCO}_{3} 25, \mathrm{KH}_{2} \mathrm{PO}_{4} 1.2$, glucose 11 and pyruvate 2). The buffer was balanced with $95 \%$ $\mathrm{O}_{2}$ and $5 \% \mathrm{CO}_{2}$, with a $\mathrm{pH}$ estimation of 7.4 and a temperature of $37^{\circ} \mathrm{C}$.

After the heart perfusion foundation, the arrangements were balanced within $30 \mathrm{~min}$ with a basal $\mathrm{CPP}$ of $70 \mathrm{cmH}_{2} \mathrm{O}$. Following the adjustment period, the perfusion pressure was diminished to 50 and $40 \mathrm{cmH}_{2} \mathrm{O}$, and afterwards, step by step expanded to $60,80,100$, and $120 \mathrm{cmH}_{2} \mathrm{O}$ to set up coronary autoregulation. Testing began following the control test to keep away from undesirable time-dependent consequences. The spironolactone application $(0.1$ and $3 \mathrm{~mol} / \mathrm{L})$ went on until accomplishing a steady stream, yet not under $5 \mathrm{~min}$ for each estimation of perfusion pressure. After the sensor (transducer BS4 73-0184, Experimetria Ltd., Budapest, Hungary) placing into the left ventricle, the accompanying cardiodynamic parameters were ceaselessly enlisted: the maximum and minimum rate of pressure development in the left ventricle (dp/dtmax, dp/dtmin), systolic and diastolic left ventricle pressure (SLVP, DLVP), pulse (HR), and coronary flow (CF) on every one of foreordained estimations of perfusion pressure $\left(40,60,80,100\right.$, and $\left.120 \mathrm{cmH}_{2} \mathrm{O}\right)$. CF was estimated by flowmetry. Every heart was its control.

\section{Biochemical analysis}

Markers of oxidative stress were estimated spectrophotometrically in the gathered examples of coronary venous effluent. Samples were collected after adjustment of the coronary flow and after medication administration for every perfusion pressure. We performed quantification of nitrites (the measure of $\mathrm{NO}$ discharged), superoxide anion radical $\left(\mathrm{O}_{2}{ }^{-}\right)$, and hydrogen peroxide $\left(\mathrm{H}_{2} \mathrm{O}_{2}\right)$ and indirect quantification of the index of lipid peroxidation using receptive thiobarbituric substances (TBARS), for all examples.

\section{Determination of hydrogen peroxide $\left(\mathrm{H}_{2} \mathrm{O}_{2}\right)$}

Estimation of hydrogen peroxide depended on the oxidation of phenol red by hydrogen peroxide in a response catalyzed by horseradish peroxidase (HRPO) [14]. A sum of 200 $\mu l$ of perfusate was accelerated with $800 \mathrm{ml}$ of freshly arranged phenol red solution, followed by the addition of $10 \mu \mathrm{l}$ of (1:20) HRPO (made ex-tempore). A sufficient volume of distilled water was utilized as a blank test (rather than coronary venous gushing). The level of $\mathrm{H}_{2} \mathrm{O}_{2}$ was measured at $610 \mathrm{~nm}$

\section{Determination of nitrites $\left(\mathrm{NO}_{2}^{-}\right)$}

Nitric oxide decays quickly to frame stable metabolite nitrite/nitrate products. Nitrites can, in this manner, be utilized as an index of NO generation using a spectrophotometric strategy utilizing the Griess reagent. Nitrites $\left(\mathrm{NO}_{2}{ }^{-}\right)$were determined as an index of NO creation with Griess reagent (forms purple diazocomplex) [15]. Briefly, $0.5 \mathrm{ml}$ of the perfusate was accelerated with $200 \mu \mathrm{l}$ of $30 \%$ sulfosalicylic acid, vortexed for $30 \mathrm{~min}$ and centrifuged at $3000 \mathrm{x}$ g. Equal volumes of the supernatant and Griess reagent containing $1 \%$ sulphanilamide in $5 \%$ phosphoric acid/ $0.1 \%$ naphthalene ethylenediamine-dihydrochloride was added and balanced out for $10 \mathrm{~min}$ in the dark and estimated spectrophotometrically at $550 \mathrm{~nm}$. Distilled water was utilized as a clear test.

\section{Determination of superoxide anion radicals $\left(\mathrm{O}_{2}^{-}\right)$}

Superoxide anion radical concentrations were estimated utilizing the NTB (Nitro Blue Tetrazolium) reagent in TRIS buffer (assay mixture) with coronary venous effluent. The estimation was performed at a wavelength of $550 \mathrm{~nm}$. Distilled water was utilized as a blank test [16].

\section{Determination of the index of lipid peroxidation measured as TBARS}

The lipid peroxidation list was determined indirectly by estimating the results of the response with thiobarbituric acid (TBARS or Thiobarbituric Acid Reactive Substances). Briefly, $1 \%$ thiobarbituric acid (TBA) in $0.05 \mathrm{M} \mathrm{NaOH}$ was incubated with coronary venous effluent at $100^{\circ} \mathrm{C}$ for $15 \mathrm{~min}$ and afterwards, spectrophotometrically estimated at a wavelength of $530 \mathrm{~nm}$. Distilled water was utilized as a blank test (17).

Drugs

STZ and spironolactone were purchased from Sigma-Aldrich Chemie GmbH Eschenstr. 5, 82024 Taufkirchen, Germany.

\section{Statistics}

Statistical investigation of experimental information incorporated the following essential descriptive statistics: the mean value $(\mathrm{X}) \pm$ standard deviation $(\mathrm{SD})$. Results and variables from healthy and diabetic rat hearts perfused with various spironolactone dosages $(0.1$ or $3 \mu \mathrm{M} / \mathrm{L})$ were compared with every parameter at each CPP. The following factual tests were utilized to test the measurable statistical significance of the outcomes and to affirm the speculation: Independent Ttest. A database analysis of the results was performed using programming software SPSS 18th (SPSS Inc., Chicago, IL, USA). P values lower than $0.05(\mathrm{p}<0.05)$ were considered to be significant, while $p$ values lower than $0.01(p<0.01)$ were viewed as highly significant. 


\section{RESULTS}

\section{Hydrogen peroxide $\left(\mathrm{H}_{2} \mathrm{O}_{2}\right)$}

After spironolactone application in the dose of $0.1 \mu \mathrm{M}$, the hydrogen peroxide levels did not significantly differ in healthy and diabetic rats (Fig 1a). However, after perfusion with $3 \mu \mathrm{M}$ of spironolactone, levels of hydrogen peroxide significantly decreased in diabetic rats when compared to healthy rats at all CPPs, with higher significance at $80-120$ $\mathrm{cmH}_{2} \mathrm{O}(\mathrm{p}<0.01)$ (Fig 2a). When we compared levels of $\mathrm{H}_{2} \mathrm{O}_{2}$ between healthy rats treated with $0.1 \mu \mathrm{M}$ and $3 \mu \mathrm{M}$ of spironolactone, no significant differences were noted at any CPP (Fig 3a). Significantly lower levels of $\mathrm{H}_{2} \mathrm{O}_{2}$ were noticed in diabetic rats treated with $3 \mu \mathrm{M}$ at 80,100 and $120 \mathrm{~cm} \mathrm{H}_{2} \mathrm{O}$ compared to diabetic rats treated with $0.1 \mu \mathrm{M}$ of spironolactone (Fig 4a). The most significant increase in the level of $\mathrm{H}_{2} \mathrm{O}_{2}$ was achieved with $0.1 \mu \mathrm{M}$ of spironolactone at CPP of $40 \mathrm{~cm} \mathrm{H}_{2} \mathrm{O}$ compared to control, while $3 \mu \mathrm{M}$ lowered the level of $\mathrm{H}_{2} \mathrm{O}_{2}$ the most in diabetic rats at $\mathrm{CPP}$ of $120 \mathrm{~cm} \mathrm{H}_{2} \mathrm{O}$ (Table 1.)

\section{Nitrites $\left(\mathrm{NO}_{2}{ }^{-}\right)$}

NO activity was measured as nitrite. Its level was significantly higher in diabetic rats perfused with $0.1 \mu \mathrm{M}$ of spironolactone than healthy rats perfused with the same dose of spironolactone at CPPs at 100 and $120 \mathrm{~cm} \mathrm{H}_{2} \mathrm{O}(\mathrm{p}<0.05)$. Simultaneously, the level of nitrites did not significantly differ at lower CPPs (Fig 1b). When diabetic and healthy hearts were perfused with $3 \mu \mathrm{M}$ of spironolactone, levels of nitrites were markedly higher in healthy hearts only at CPP at 120 $\mathrm{cm} \mathrm{H}_{2} \mathrm{O}(\mathrm{p}<0.05)$, while at lower CPPs, no significant differences were observed, but there is a noticeable trend in the rise of the level of nitrites in healthy hearts (Fig 2b). The same evident trend was also observed when we compared levels of nitrites between healthy rats treated with $0.1 \mu \mathrm{M}$ and $3 \mu \mathrm{M}$ of spironolactone, with significantly higher levels of nitrites in healthy rats treated with $3 \mu \mathrm{M}$ of spironolactone when compared to healthy rats treated with $0.1 \mu \mathrm{M}$ of spironolactone (Fig 3b). In contrast, when we compared the level of nitrites in diabetic rats treated with $0.1 \mu \mathrm{M}$ and $3 \mu \mathrm{M}$ of spironolactone, there were no significant differences in nitrites' levels (Fig 4b). The dose of $0.1 \mu \mathrm{M}$ of spironolactone increased the level of $\mathrm{NO}_{2}^{-}$the most in healthy rats compared to healthy control at $\mathrm{CPP} 40 \mathrm{~cm} \mathrm{H}_{2} \mathrm{O}$, while the most significant decrease in the level of $\mathrm{NO}_{2}{ }^{-}$was observed between the same rats at $\mathrm{CPP} 120 \mathrm{~cm} \mathrm{H}_{2} \mathrm{O}$ (Table 1.).

\section{Superoxide anion radical $\left(\mathrm{O}_{2}^{-}\right)$}

In diabetic rats perfused with $0.1 \mu \mathrm{M}$ of spironolactone compared with healthy rats perfused with the same dose of spironolactone level of $\mathrm{O}_{2}{ }^{-}$was significantly increased at 80 $-120 \mathrm{~cm} \mathrm{H}_{2} \mathrm{O}(\mathrm{p}<0.01)$ (Fig 1c), but when both groups were perfused with $3 \mu \mathrm{M}$ of spironolactone, levels of $\mathrm{O}_{2}^{-}$were significantly higher in healthy rats at 40, 60 and $120 \mathrm{~cm} \mathrm{H}_{2} \mathrm{O}$ $(\mathrm{p}<0.05)$ (Fig 2c). Level of $\mathrm{O}_{2}^{-}$did not significantly differ between healthy rats treated with $0.1 \mu \mathrm{M}$ and $3 \mu \mathrm{M}$ of spironolactone (Fig 3c). However, a significantly higher level of
$\mathrm{O}_{2}^{-}$was observed in diabetic rats treated with $0.1 \mu \mathrm{M}$ of spironolactone compared to diabetic rats treated with $3 \mu \mathrm{M}$ od spironolactone at $60,80,100$ and $120 \mathrm{~cm} \mathrm{H}_{2} \mathrm{O}$ (Fig 4c). Spironolactone in the dose of $0.1 \mu \mathrm{M}$ increased the level of $\mathrm{O}_{2}^{-}$ for $67.14 \%$ in diabetic rats when compared with diabetic control at $\mathrm{CPP} 120 \mathrm{~cm} \mathrm{H}_{2} \mathrm{O}$, while the same quantity of spironolactone decreased the level of $\mathrm{O}_{2}^{-}$for $53.58 \%$ in healthy rats when compared to healthy control at CPP $60 \mathrm{~cm} \mathrm{H}_{2} \mathrm{O}$ (Table 1.).

\section{Index of lipid peroxidation (measured as TBARS)}

After spironolactone application in the dose of $0.1 \mu \mathrm{M}$, the levels of TBARS did not significantly differ in healthy and diabetic rats (Fig 1d). After perfusion with $3 \mu \mathrm{M}$ of spironolactone in diabetic rats, significantly lower levels of TBARS was observed at $80-120 \mathrm{~cm} \mathrm{H}_{2} \mathrm{O}$ (Fig 2d). When we compared the level of TBARS between healthy rats treated with $0.1 \mu \mathrm{M}$ and $3 \mu \mathrm{M}$ of spironolactone, in the group treated with $3 \mu \mathrm{M}$ of spironolactone, we noticed significant higher values compared to the group treated with $0.1 \mu \mathrm{M}$ of spironolactone at $80-120 \mathrm{~cm} \mathrm{H}_{2} \mathrm{O}$ (Fig 3d). Significantly lower levels of TBARS were observed in diabetic rats treated with $3 \mu \mathrm{M}$ of spironolactone when we compared them to diabetic rats treated with $0.1 \mu \mathrm{M}$ of spironolactone (Fig 4d). Levels of TBARS increased the most when $3 \mu \mathrm{M}$ of spironolactone was applied to healthy rats at $\mathrm{CPP}$ of $120 \mathrm{~cm} \mathrm{H}_{2} \mathrm{O}$ compared to healthy control. In contrast, spironolactone in the same dose lowered TBARS the most in diabetic rats at CPP $80 \mathrm{~cm} \mathrm{H}_{2} \mathrm{O}$ (Table 1.).

Figure 1. Parameters of oxidative stress in healthy rats perfused with $0.1 \mu \mathrm{M}$ of spironolactone compared with diabetic rats perfused with $0.1 \mu \mathrm{M}$ of spironolactone.
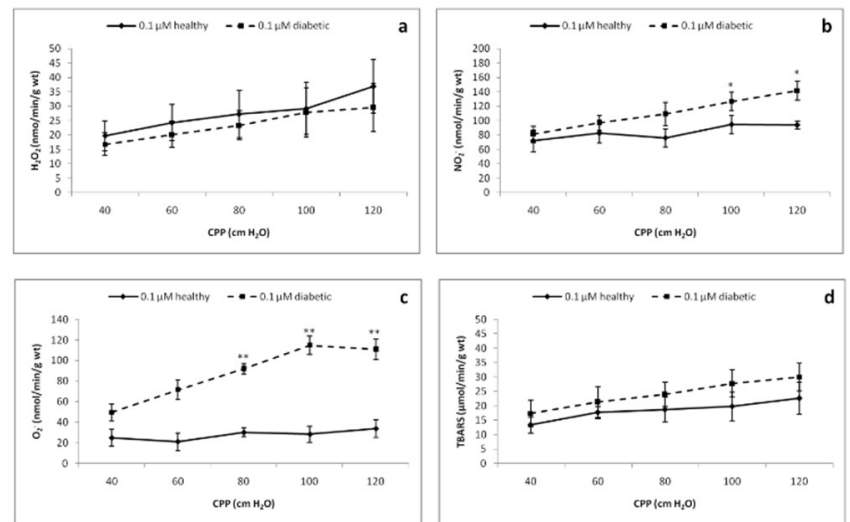

(a) Hydrogen peroxide (H2O2) (b) Nitrites (NO2-) (c) Superoxide anion radical (O2-) (d) Index of lipid peroxidation (measured as TBARS). Data is presented as mean $\pm \mathrm{SD}$. CPP, coronary perfusion pressure. 
Figure 2. Parameters of oxidative stress in healthy rats perfused with $3 \mu \mathrm{M}$ of spironolactone compared with diabetic rats perfused with $3 \mu \mathrm{M}$ of spironolactone.
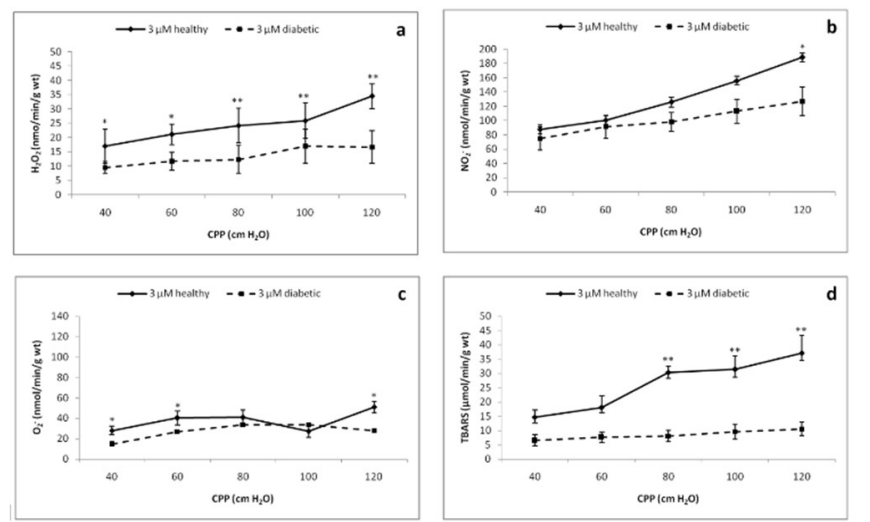

(a) Hydrogen peroxide (H2O2) (b) Nitrites (NO2-) (c) Superoxide anion radical (O2-) (d) Index of lipid peroxidation (measured as TBARS). Data is presented as mean \pm SD. CPP, coronary perfusion pressure.
Figure 3. Parameters of oxidative stress in healthy rats perfused with $0.1 \mu \mathrm{M}$ of spironolactone compared with healthy rats perfused with $3 \mu \mathrm{M}$ of spironolactone.
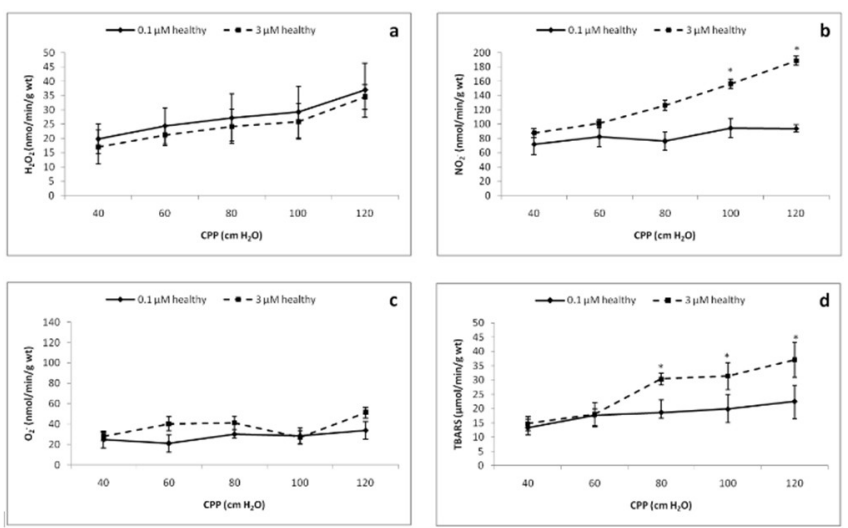

(a) Hydrogen peroxide $\left(\mathrm{H}_{2} \mathrm{O}_{2}\right)$ (b) Nitrites $\left(\mathrm{NO}_{2}^{-}\right)$(c) Superoxide anion radical $\left(\mathrm{O}_{2}^{-}\right)$(d) Index of lipid peroxidation (measured as TBARS). Data is presented as mean \pm SD. CPP, coronary perfusion pressure.

Figure 4. Parameters of oxidative stress in diabetic rats perfused with $0.1 \mu \mathrm{M}$ of spironolactone compared with diabetic rats perfused with $3 \mu \mathrm{M}$ of spironolactone.
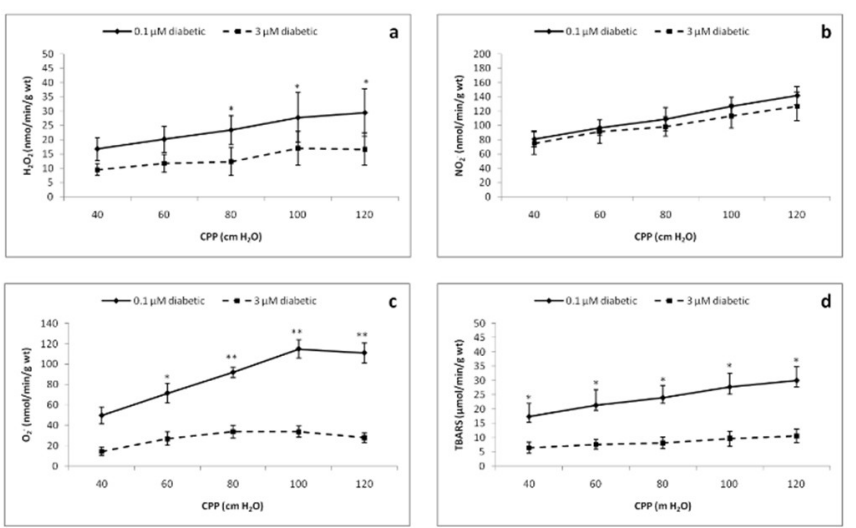

(a) Hydrogen peroxide $\left(\mathrm{H}_{2} \mathrm{O}_{2}\right)$ (b) Nitrites $\left(\mathrm{NO}_{2}^{-}\right)$

(c) Superoxide anion radical $\left(\mathrm{O}_{2}^{-}\right)$(d) Index of lipid peroxidation (measured as TBARS).

Data is presented as mean $\pm \mathrm{SD}$. CPP, coronary perfusion pressure.

Table 1. Percentage of reduction or increase in the each of the parameters of oxidative stress in healthy and diabetic rats treated with different spironolactone doses.

\begin{tabular}{|c|c|c|c|c|c|c|}
\hline & & $\stackrel{40}{\mathrm{cmH}_{2} \mathrm{O}}$ & $\begin{array}{c}60 \\
\mathrm{cmH}_{2} \mathrm{O}\end{array}$ & $\begin{array}{c}80 \\
\mathrm{cmH}_{2} \mathrm{O}\end{array}$ & $\begin{array}{c}100 \\
\mathrm{cmH}_{2} \mathrm{O}\end{array}$ & $\begin{array}{c}120 \\
\mathrm{cmH}_{2} \mathrm{O}\end{array}$ \\
\hline \multirow{4}{*}{ 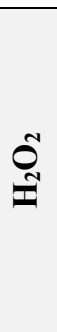 } & $\begin{array}{c}0.1 \mu \mathrm{M} \text { spironolactone healthy vs. } \\
\text { control }\end{array}$ & +20.49 & +1.34 & +1.30 & -7.57 & 0.00 \\
\hline & $\begin{array}{c}3 \mu \mathrm{M} \text { spironolactone } \\
\text { healthy vs. control }\end{array}$ & +11.12 & -3.88 & +0.79 & -12.62 & +9.40 \\
\hline & $\begin{array}{l}0.1 \mu \mathrm{M} \text { spironolactone } \\
\text { diabetic vs. diabetic }\end{array}$ & -0.12 & -11.62 & -0.28 & +8.73 & -8.08 \\
\hline & $\begin{array}{c}3 \mu \mathrm{M} \text { spironolactone diabetic vs. } \\
\text { diabetic }\end{array}$ & -12.22 & -33.73 & -37.84 & -20.12 & -43.83 \\
\hline
\end{tabular}




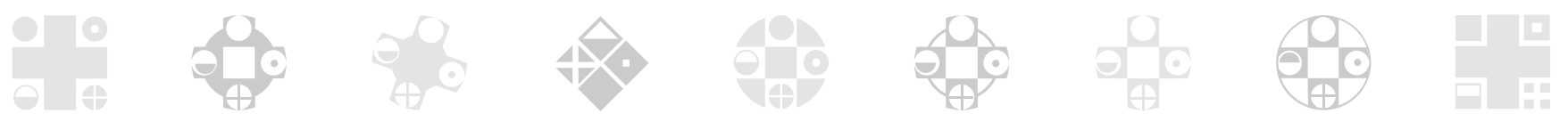

\begin{tabular}{|c|c|c|c|c|c|c|}
\hline & & $\stackrel{40}{\mathrm{cmH}_{2} \mathrm{O}}$ & $\begin{array}{c}60 \\
\mathrm{cmH}_{2} \mathrm{O}\end{array}$ & $\begin{array}{c}80 \\
\mathrm{cmH}_{2} \mathrm{O}\end{array}$ & $\begin{array}{c}100 \\
\mathrm{cmH}_{2} \mathrm{O}\end{array}$ & $\begin{array}{c}120 \\
\mathrm{cmH}_{2} \mathrm{O}\end{array}$ \\
\hline \multirow{4}{*}{ '̇ } & $\begin{array}{c}0.1 \mu \mathrm{M} \text { spironolactone healthy vs. } \\
\text { control }\end{array}$ & +13.69 & -10.83 & -20.12 & -19.92 & -31.26 \\
\hline & $\begin{array}{c}3 \mu \mathrm{M} \text { spironolactone } \\
\text { healthy vs. control }\end{array}$ & -2.03 & -13.64 & -0.36 & -4.74 & +0.90 \\
\hline & $\begin{array}{l}0.1 \mu \mathrm{M} \text { spironolactone } \\
\text { diabetic vs. diabetic }\end{array}$ & +4.12 & -6.74 & -4.91 & +1.26 & -0.98 \\
\hline & $\begin{array}{c}3 \mu \mathrm{M} \text { spironolactone diabetic vs. } \\
\text { diabetic }\end{array}$ & -3.46 & -11.98 & -14.09 & -9.54 & -11.25 \\
\hline \multirow{4}{*}{ Ô } & $\begin{array}{c}0.1 \mu \mathrm{M} \text { spironolactone } \\
\text { healthy vs. control }\end{array}$ & +5.55 & -53.58 & -14.75 & +41.34 & -16.96 \\
\hline & $\begin{array}{c}3 \mu \mathrm{M} \text { spironolactone } \\
\text { healthy vs. control }\end{array}$ & +16.83 & -6.04 & -16.97 & -20.30 & -11.92 \\
\hline & $\begin{array}{c}0.1 \mu \mathrm{M} \text { spironolactone diabetic } \\
\text { vs. diabetic }\end{array}$ & -21.85 & -3.80 & +32.66 & +19.34 & +67.14 \\
\hline & $\begin{array}{c}3 \mu \mathrm{M} \text { spironolactone diabetic vs. } \\
\text { diabetic }\end{array}$ & +6.31 & -32.84 & -25.24 & -15.17 & -46.94 \\
\hline \multirow{4}{*}{$\underset{\mathscr{a}}{\mathscr{a}}$} & $\begin{array}{c}0.1 \mu \mathrm{M} \text { spironolactone healthy vs. } \\
\text { control }\end{array}$ & +7.85 & +1.32 & -6.91 & -10.89 & -9.93 \\
\hline & $\begin{array}{c}3 \mu \mathrm{M} \text { spironolactone } \\
\text { healthy vs. control }\end{array}$ & +7.64 & +5.60 & +27.74 & +28.50 & +31.63 \\
\hline & $\begin{array}{c}0.1 \mu \mathrm{M} \text { spironolactone diabetic } \\
\text { vs. diabetic }\end{array}$ & +5.25 & -6.02 & -7.06 & +0.60 & -3.87 \\
\hline & $\begin{array}{c}3 \mu \mathrm{M} \text { spironolactone diabetic vs. } \\
\text { diabetic }\end{array}$ & -13.61 & -48.17 & -49.53 & -46.99 & -47.15 \\
\hline
\end{tabular}

Percentage of reduction or increase in the each of the parameters of oxidative stress in healthy rats, healthy rats treated with $0.1 \mu \mathrm{M}$ and $3 \mu \mathrm{M}$ of spironolactone and diabetic rats treated with $0.1 \mu \mathrm{M}$ and $3 \mu \mathrm{M}$ of spironolactone. Sign (-) stands for reduction and sign $(+)$ stands for increase in the level of the parameters of oxidative stress. Data is presented as percentage.

\section{DISCUSSION}

The present study aimed to assess the acute effect of spironolactone administration on oxidative stress parameters in STZ-induced DM isolated heart rats. Besides, we have also examined the acute effect of different spironolactone doses on oxidative stress parameters in the above mentioned isolated heart rats.

Besides hypertension, DM is one of the most common factors contributing to CVD, putting CVD at the top of the scale of mortality worldwide. Acceleration of atherosclerosis increases the arteries' stiffness; thus, earlier onset of CVD, such as coronary artery disease, heart failure, arrhythmias, is one of the primary mechanisms by which DM contributes to the development of CVD.

Development of diabetic cardiomyopathy, characterized by interstitial and perivascular fibrosis, thickening of basal membranes of capillaries and hypertrophy of cardiomyocytes are one of the most critical consequences of DM [18-21]. State of hyperglycemia through activation of different signal pathways leads to inflammation, increased ROS synthesis, and remodelling of the extracellular matrix of heart muscle
[22]. Those mechanisms lead to myocardial fibrosis, respectively increased rigidity, reduced ability for myocardial relaxation and increased stiffness of the endocardium. Abnormalities in calcium homeostasis, increased synthesis of ROS, and mitochondrial dysfunction are also some of the mechanisms involved in the development of diabetic cardiomyopathy. Simultaneously, activation of RAAS, one of the main ones, plays a crucial role in manifesting the consequences of chronic hyperglycemia [23, 24]. One of RAAS activation effects is increased ROS synthesis and thus changes in activation genes leading to increased fibrosis of the heart, apoptosis, and necrosis [25]. Beside increased ROS synthesis, consequential activation of angiotensin II receptors type 1 and MR can also lead to myocardial fibrosis [26]. When activation of angiotensin II receptors type 1 and MR are compared, AT1 receptor blockade protects the heart from diabetic complications short-termly, while MR blockade provides longterm protection [27].

For chronic administration of spironolactone, MR's nonselective antagonist has been previously reported to lower the myocardial fibrosis, however, without effect on 
cardiodynamic parameters [28]. Our previous research has documented a different impact of acute spironolactone administration on healthy and diabetic rats with better effects of higher spironolactone doses in diabetic rats, while in a healthy one, the same effect was observed with lower spironolactone doses [9]. And our current findings are consistent with the previous one, showing the same effect of spironolactone on oxidative stress parameters as on parameters of cardiac dynamics in healthy and diabetic hearts. Levels of $\mathrm{H}_{2} \mathrm{O}_{2}$ were significantly lower in the group of diabetic rats treated with $3 \mu \mathrm{M}$ then in the healthy rats treated with the same dose of spironolactone. Simultaneously, no significant differences were noted when diabetic and healthy rats treated with $0.1 \mu \mathrm{M}$ of spironolactone were compared and when healthy rats treated with $0.1 \mu \mathrm{M}$ were compared with healthy rats treated with $3 \mu \mathrm{M}$ of spironolactone. Previous research has concluded that chronic administration of spironolactone lowers levels of $\mathrm{H}_{2} \mathrm{O}_{2}$, while it has also been proved that spironolactone enhances the activity of catalase, an antioxidant enzyme with effects on $\mathrm{H}_{2} \mathrm{O}_{2}[29,30]$. Levels of $\mathrm{NO}_{2}{ }^{-}$did not significantly differ between our groups, except when we compared healthy and diabetic rats treated with $0.1 \mu \mathrm{M}$ of spironolactone at higher values of CPP where better effect were observed in healthy rats; and when we compared healthy rats treated with $0.1 \mu \mathrm{M}$ of spironolactone and healthy rats treated with $3 \mu \mathrm{M}$ of spironolactone again at higher values of CPP ( 100 and $120 \mathrm{~cm} \mathrm{H}_{2} \mathrm{O}$ ), confirming our earlier conclusion that spironolactone has better effects in heathy rats when given in lower doses. Similar results were observed when we looked at $\mathrm{O}_{2}{ }^{-}$levels, as well as TBARS levels.

Some of the findings we observed in our previously published research regarding different effects of different spironolactone doses on parameters of cardiodynamics could be explained by these findings of oxidative stress. In the literature, spironolactone improved eNOS, endothelial nitric oxide synthase improving coronary flow [3]. It has also been reported that spironolactone improves $\mathrm{NO} /$ soluble guanylyl cyclase mediated response inducing vasodilatation [30]. Beside improved function of eNOS, it has been shown that vitamin E levels were significantly higher in STZ-induced DM rat hearts that were treated with spironolactone, either by its enhanced production or suppressed consumption [3]. It has also been shown that MR antagonists have only partial protection in diabetic eNOS knock-out mice in comparison to fully protected diabetic wild-type mice [31]. Spironolactone also leads to lower levels of TBARS, which can point protective effects of spironolactone towards biomembranes, which contain numerous polyunsaturated free fatty acids.

In summary, different spironolactone doses achieved different effects on parameters of oxidative stress. While better effects in healthy rats were achieved with lower amounts of spironolactone, in diabetic rats, better outcomes were achieved with higher doses of spironolactone. These results coincide with our previous results regarding cardiodynamic parameters. Therefore, one explanation for the same effect of different spironolactone doses on cardiodynamic parameters in diabetic and healthy rats could be that the higher the dose of spironolactone, the better its impact on oxidative stress and, therefore, cardiac function. It has been shown that the state of hyperglycemia enhances MR transcriptional activity, and the reason for better spironolactone effect on diabetic hearts in higher dose could be explained by overexpression of MR in diabetic hearts, thus blocking it with higher spironolactone concentrations better result is achieved [32]. In healthy hearts, the same effect is observed with lower spironolactone concentrations because there is no MR overexpression. These discoveries likewise concur with the recently revealed level after which perfusion with higher spironolactone groupings does not have any extra impact on myocardial contractility [33]. Besides the reported plateau for spironolactone, it has also been shown that different spironolactone doses did not change the concentrations of pro-inflammatory cytokines (IL-1 $\beta$, IL-6 and IL-8) in human coronary artery endothelial cells treated with 5.5mM dextrose [34].

Our study's main limitations are the lack of a causal relationship between the spironolactone effect on cardiodynamics and on parameters of oxidative stress. While oxidative stress induces MR activation, oxidative stress is subsequently increased by MR activation in a feedback loop, we could not determine whether the spironolactone effect is achieved directly by influencing cardiodynamic parameters and consequently changing the levels of parameters of oxidative stress or primarily by modification of parameters of oxidative stress and after that cardiodynamic parameters, however, the causal link exists $[35,36]$. Therefore, further research is needed to investigate the spironolactone effect on the relationship between cardiodynamic and parameters of oxidative stress and determine the definitive mechanism of action of different spironolactone dosage on diabetic hearts.

\section{CONCLUSION}

Spironolactone, a non-selective MR antagonist, achieved different effects on oxidative stress parameters when given acutely in different doses in diabetic and healthy rats. In lower doses, spironolactone's acute administration lowered the parameters of oxidative stress in healthy rats better than higher doses of spironolactone. In contrast, in the diabetic group, acute effects of higher doses of spironolactone lowered oxidative stress parameters better than lower doses of spironolactone.

\section{ACKNOWLEDGEMENTS}

The work has been done at the Department of Physiology, Faculty of Medical Sciences, University of Kragujevac, Kragujevac, Serbia.

\section{CONFLICT OF INTEREST}

The authors report no conflicts of interest. 


\section{REFERENCES}

1. Zimmet P, Alberti KG, Shaw J. Global and societal implications of the diabetes epidemic. Nature 2001;414:782-787.

2. Leon BM, Maddox TM. Diabetes and cardiovascular disease: Epidemiology, biological mechanisms, treatment recommendations and future research. World J Diabetes 2015;6(13):1246-1258.

3. Mayyas F, Alzoubi KH, Bonyan R. The role of spironolactone on myocardial oxidative stress in rat model of streptozotocin-induced diabetes. Cardiovasc Ther 2017;35(2): e12242.

4. Silva MAB, Bruder-Nascimento T, Cau SBA, Lopes RAM, Mestriner FLAC, Fais RS, et al. Spironolcatone treatment attenuates vascular dysfunction in type 2 diabetic mice by decreasing oxidative stress and restoring NO/GC signaling. Front Physiol 2015;6:269.

5. Silva MA, Cau SB, Lopes RA, Manzato CP, Neves KB, Bruder-Nascimento T, et al. Mineralocorticoid receptor blockade prevents vascular remodeling in a rodent model of type 2 diabetes mellitus. Clin Sci (Lond.) 2015;129(7):533-545.

6. Delcayre C. and Silvestre JS. Aldosterone and the heart: towards a physiological function? Cardiovasc Res 1999;43(1):7-12.

7. Patel BM, Kakadiya J, Goyal RK, Mehta AA. Effect of Spironolactone on Cardiovascular Complications Associated with Type-2 Diabetes in Rats. Exp Clin Endocrinol Diabetes 2013;121:441-447.

8. Garg R, Rao AD, Baimas-George M, Hurwitz S, Foster $\mathrm{C}$, Shah RV, et al. Mineralocorticoid receptor blockade improves coronary microvascular function in individuals with type 2 diabetes. Diabetes 2015;64(1):236-42.

9. Vranic A, Simovic S, Ristic P, Nikolic T, Stojic I, Srejovic I, et al.. The acute effects of different spironolactone doses on cardiac function in streptozotocin-induced diabetic rats. Can $\mathrm{J}$ Physiol Pharmacol 2017;95(11):1343-1350.

10. Stas S, Whaley-Connell A, Habibi J, Appesh L, Hayden MR, Karuparthi PR, et al. Mineralocorticoid receptor blockade attenuates chronic overexpression of the reninangiotensin-aldosterone system stimulation of reduced nicotinamide adenine dinucleotide phosphate oxidase and cardiac remodeling. Endocrinology 2007;148:3773 -3780 .

11. Toda N, Nakanishi S, Tanabe S. Aldosterone affects blood flow and vascular tone regulated by endotheliumderived NO: therapeutic implications. Br J Pharmacol 2013;168:519-533.

12. Hollenberg NK, Stevanovic R, Agarwal A, Lansang MC, Price DA, Laffel LM, et al. Plasma aldosterone concentration in the patient with diabetes mellitus. Kidney Int 2004;65:1435-1439.

13. 13. Tveden-Nyborg P, Bergmann TK, Lykkesfeldt J. Basic \& Clinical Pharmacology \& Toxicology Policy for Experimental and Clinical studies. Basic Clin Pharmacol Toxicol 2018;123(3):233-235.
14. Pick E, Keisari Y. A simple colometric method for the measurement of hydrogen peroxide by cells in culture. J Immunol Methods 1980;38:161-170.

15. Green LC, Wagner DA, Glogowski J, Skipper PI, Wishnok JS, Tannenbaum SR Analysis of nitrate, nitrite and [15N] nitrate in biological fluids. Anal Biochem 1982;126:131-138.

16. Auclair C, Voisin E. Nitroblue Tetrazolium reduction. In: Greenwald RA (ed) Handbook of methods for oxygen radical research. CRP Press, Boca Raton, 1985. pp 123-132.

17. Ohkawa H, Ohishi N, Yagi K. Assay for lipid peroxides in animal tissues by thiobarbituric acid reaction. Anal Biochem 1979;95:351-358.

18. Hayat SA, Patel B, Khattar RS, Malik RA. Diabetic cardiomyopathy: mechanisms, diagnosis and treatment Clinical Science 2004;107:539-557.

19. Li YW, Aeno WS. Diabetes Mellitus and Cardiovascular Disease. J Clinic Experiment Cardiol 2011;2:114.

20. Rubler S, Dlugash J, Yuceoglu YZ, Kumral T, Branwood AW, Grishman A. New type of cardiomyopathy associated with diabetic glomerulosclerosis. Am J Cardiol 1972;30:595-602.

21. Van Hoeven KH, Factor SM. A comparison of the pathological spectrum of hypertensive, diabetic, and hypertensive - diabetic heart disease. Circulation 1990;82:848 85.

22. Poornima IG, Parkih P, Shanon RP. Diabetic Cardiomyopathy: search for unifying hypoyhesis Circ Res 2006;98:596-605.

23. Watanabe K, Thandavarayan RA, Harima M, Sari FR, Gurusamy N, Veeraveedu PT, et al. Role of Differential Signaling Pathways and Oxidative Stress in Diabetic Cardiomyopathy. Curr Cardiol Rev 2010;6:280-290.

24. Hunyady L, Catt KJ. Pleiotropic AT1 receptor signaling pathways mediating physiological and pathogenic actions of angiotensin II. Molecular Endocrinol 2006;20:953-970.

25. Frustaci A, Kajstura J, Chimenti C, Jakoniuk I, Leri A, Maseri A. et al. Myocardial cell death in human diabetes. Circ Res 2000;87:1123-1132.

26. Robert V, Heymes C, Silvestre JS. Angiotensin AT1receptor subtype as a cardiac target of aldosterone: role in aldosterone salt induced fibrosis. Hypertension 1999;33:981-986.

27. Nagatomo $\mathrm{Y}$, Meguro T, Ito H, Koide K, Anzai T, Fukuda K. et al. Significance of AT1 receptor independent activation of mineralocorticoid receptor in murine diabetic cardiomyopathy. PLoS One 2014;9(3):e93145.

28. Verma S, Violet GY, Badiwala M, Anderson JT, Mc Niel LH. Working heart function in diabetes is not improved by spironolactone treatment Can J Physiol Pharmacol 2003;81:493-496.

29. Ojeda-Cervantes M, Barrera-Chimal J, Alberú J, PérezVillalva R, Morales-Buenrostro LE, Bobadilla NA. Mineralocorticoid receptor blockade reduced oxidative stress in renal transplant recipients: a double-blind, randomized pilot study. Am J Nephrol 2013;37(5):481-90. 
30. Silva MA, Bruder-Nascimento T, Cau SB, Lopes RA, Mestriner FL, Fais RS, Touyz, RM, Tostes RC. Spironolactone treatment attenuates vascular dysfunction in type 2 diabetic mice by decreasing oxidative stress and restoring NO/GC signaling. Front Physiol 2015;6:269.

31. Kosugi T, Heining M, Nakayama T, Matsuo S, Nakagawa T. eNOS Knockout Mice with Advanced Diabetic Nephropathy Have Less Benefit from Renin-Angiotensin Blockade than from Aldosterone Receptor Antagonists. Am J Path 2010;176(2):619-629.

32. Hayashi T, Shibata H, Kurihara I, Yokota K, Mitsuishi Y, Ohashi, K, et al. High Glucose Stimulates Mineralocorticoid Receptor Transcriptional Activity Through the Protein Kinase C $\beta$ Signaling. Int Heart J 2017;58:794802.

33. Barbato JC, Mulrow PJ, Shapiro JI and Franco-Saenz R. Rapid effects of aldosterone and spironolactone in the isolated working rat heart. Hypertension 2002;40(2):130-135.

34. Haas MJ, Jurado-Flores M, Hammoud R, Feng V, Gonzales K, Onstead-Haas L, Mooradian AD. The Effects of Known Cardioprotective Drugs on Proinflammatory Cytokine Secretion from Human Coronary Artery Endothelial Cells. Am J Therapeut 2019;26(3):e321-e332.

35. Shibata S, Nagase M, Yoshida S, Kawarazaki W, Kurihara H, Tanaka H, Miyoshi J. Modification of mineralocorticoid receptor function by Rac1 GTPase: implication in proteinuric kidney disease. Nat Med 2008; 14:1370-1376.

36. Kawakami-Moori F and Shimosawa T. Oxidative Stress and Mineralocorticoid Receptor Signaling in the Brain: Possible Therapeutic Targets for Dementia. Ann Clin Exp Hypertesion 2012;2(2):1015-1020. 